\title{
HUMANA EKOLOGIJA I TEHNOLOGIJA TRANSCENDENTNE KOMUNIKACIJE
}

\author{
Juraj Plenković \\ Sveučilište u Rijeci, Rijeka, Hrvatska
}

\begin{abstract}
Sažetak
U radu se dijakronijski i sinkronijski analiziraju povijesne i tehnološke mogućnosti ekologije i transendentne komunikacije provedbenom multilateralnom metodologijom postignuća suvremene ekološke i komunikološke transcendentne misli. Opća je spoznaja da se svijet nalazi u velikoj globalnoj krizi, a ekologija i tehnologija u novom humanom izazovu koji postaje dominantna odrednica ljudskog promišljanja, ponašanja i djelovanja u suvremenom komunikacijskom i tehnološkom svijetu. Suvremeni život postavlja humanu ekologiju u prvi plan, pozornošću kako se tehnologija razvija u okruženju tehnologije transcendentne komunikacije. Autor u radu ukazuje kako se tehnologija i ekologija ne smije prepustiti stihiji, nego se sve tehnologije moraju humano, komunikacijski i stvaralački primjenjivati, kako bi se maksimalno zadovoljili postojeći tehnološki uvjeti komunikativnog okruženja, prostora, kulture, tradicije i edukativne osposobljenosti svih građana.
\end{abstract}

\section{Ključne riječi}

ekologija, komunikacija, humanost

\section{Pristup problemu}

U svim vremenima ekologija i njena tematika bile su u središtu ljudske teorije i prakse.

Ona se tek u prošlom stoljeću znanstveno osvijestila te je danas postala glavna znanost za održanje Zemlje i čovjeka. U svojoj dugoj povijesti ekologija je kao teorija i praksa prešla nekoliko razvojnih etapa. Na jedan intuitivno-religijski način prvi su spoznali značenje ekologije Kinezi. Konfucije je učinio još jedan korak dalje te je, moglo bi se reći, posve racionalno tražio od čovjeka i vladara da uvijek poštuje sredinu: između istoka i zapada, između sjevera i juga, a nadasve između čovjeka i opće kozmičke promisli. Ova njegova misao danas dobiva posebno značenje jer smo jednostranim razvojem tehnike prekoračili tu središnju točku sveopćeg uravnoteženja. Naime, parcijalno smo zagospodarili svim resursima Zemlje, ali smo uz gospo- darske koristi dobili i negativnu pojavu onečišćenja: zraka, zemlje i vodâ. Zahvaljujući razvoju tehnike i tehnologije stvorena su moćna oružja od kojih ginu milijuni ljudi. XX. stoljeće zato je s pravom nazvano stoljećem «smrti» jer je $u$ njemu pobijeno više ljudi nego u cijeloj dosadašnjoj povijesti. Kako je i naša današnja ekološka svijest romantičarska, nužno se postavlja pitanje što i kako dalje s ekologijom, kad od nje osim lijepih snova i predviđanja ne ostaje ništa. Naime, evidentno je kako upravo najrazvijenije zemlje krše proklamacije o održavanju čiste vode, zemlje i zraka, a na planu međuljudskih i međudržavnih odnosa - Mira kao preduvjeta bez kojega se ne može postići uravnotežavanje. Budući da se bavim ovom problematikom, shvatio sam gdje je problem svih problema u ekološkoj teoriji i praksi. To je epistemološka pogreška pars pro toto (dio umjesto cjeline). Naime, zbog osobnih ograničenja nitko ne vidi cjelinu pa 
zbog toga stalno pojedine spoznate dijelove pogrešno proglašava cjelinom. Budući da ti dijelovi ne korespondiraju s kozmičkom cjelinom kao makro-sustavom, nije rijedak slučaj da se čini i druga logička pogreška, proton pseudos (pogrešna pretpostavka). Kako su ove temeljne pogreške uzrokom nevolja u pojedinačnoj i skupnoj egzistenciji ljudi, smisao je da se u rješavanju ekološkog problema priđe epistemologijom multilateralnog i multidisciplinarnog proučavanja kako u ekološkim istraživanjima izbjeći jednostranost i zaslijepljenost učenjaka koji ne vide da se u shvaćanju jedinstva raznolikosti (unitas multiplex) može izići iz pozitivističkoga sljepila i glorifikacije parcijalnog.

Da je tomu tako, danas to uviđaju mnogi intelektualci, a svojom masovnim prosvjedima diljem cijeloga svijeta i mali ljudi dižu svoj glas protiv apsurda $\mathrm{u}$ kojemu se nalazi suvremeni svijet. Naime, globalizam je, kao što je poznato, na svom početku nekritički ispalio pogrešnu maksimu da je globalizam takav makro-sustav u kojemu nitko ne gubi, a svi dobivaju.

2. Razvoj humane ekološke komunikativne misli

Ekologija je stara koliko i čovjek, a kao znanost se tek danas osvješćuje i postaje vodeća znanost u III. tisućljeću /1/ je istakao da čovjek živi, radi i razvija se u rasponu od akomodacije do asimilacije. To su i danas dva osnovna antropološka modela. Asimilacija obuhvaća aktivni odnos prema cjelokupnom ljudskom okolišu. To se najbolje vidi $\mathrm{u}$ procesu hranidbe gdje čovjek vlastitom energijom iz prirode uzima hranjive tvari koje $\mathrm{u}$ probavnome traktu prerađuje $\mathrm{u}$ nove supstancije kao što su bjelančevine, enzimi i vitamini. Ono pak što ne može transformirati, tome se prilagođuje ili akomodira, tj. pasivno se prema tome odnosi: od kiše i snijega se štiti odjećom i vatrom, pred prirodnim nepogodama bezglavo bježi, sklanja se, spiljskim staništima i sojenicama štiti se od jačih zvijeri itd. U prvoj etapi svoga razvoja Homo erectus (uspravni čovjek, od oko 2 milijuna do 1,5 milijun godina prije Krista), samo se prilagođavao i skupljao gotove plodove $u$ prirodi. U drugoj etapi, kad se čovjek preobrazio u Homo habilisa (vještoga čovjeka, od 500 tisuća do 80 tisuća godina prije
Krista), on sve više aktivno nastupa prema prirodi: krči šume, pripitomljava životinje, uzgaja jestivo bilje, plovi na splavima i izrađuje oružje i oruđe, što znači da je iz pasivnog skupljanja i akomodacije počeo prelaziti $u$ aktivno djelovanje asimilacijom. Rad je $u$ to doba osviješten $i$ pomoću kinetičke komunikacije organiziran $\mathrm{u}$ tzv. organske i socijetarne naturalne tvornice. Prvi oblik bio je naturalna tvornica u kojoj već postoji podjela rada, nadziranje radnoga procesa i utvrđivanje odgovornosti. Prema organizaciji skupnog lova na mamuta i druge životinje koje su jače od čovjeka vidi se i današnja struktura svake organizacije: cilj djelatnosti (namirenje prehrambenih potreba), podjela rada (skupina koja kamenim alatkama kopa stupicu, skupina koja kamenim sjekirama siječe grane kojima će se stupica prekriti, grupa koja iskopanom zemljom pokriva natkrivenu zamku, grupa koja bakljama natjeruje zvijer $u$ pravcu kamuflirane stupice i grupa koja, nakon što zvijer upadne u stupicu, vrši tehnološku obradu). U ovoj etapi kombinacije akomodacije i asimilacije čovječanstvo je postajalo brojnije. U okvirima asimilacije usvajaju se i duhovne vještine te nastaje kultura i prve škole. Kada je živa čovjekova memorija postala prekapacitirana (računa se da je granica bila zapamćivanje oko 30 tisuća riječi), javljaju se prvi oblici ekstrapsihičke memorije (pismo) koji će biti pretpostavka za ubrzani tehnološki razvitak: izum pluga, tropoljni sustav obrade zemlje, rudnici te izumi kompasa, baruta i tiskarstva s kojima se razvija novi tip modernoga čovjeka - sinteze Homo creatusa kao prirodnoga stvora i Homo sapiensa koji sve više i jače mijenja prirodu. U početku to mijenjanje nije bilo toliko da bi ugrozilo početnu kozmičku prestabiliranu harmoniju (Leibniz), ali od renesanse do danas tehnologija i industrijska djelatnost čovjeka je temeljito poljuljala tu prestabiliranu prirodnu ravnotežu. Pod utjecajem novih izuma (zrakoplova, podmornica, željeznice, automobila do kozmičkih letjelica) počeo se razvijati liberalistički svjetonazor koji je u svom zanosu dokinuo Boga i moralno-socijalno ljudsko ponašanje. Nasuprot akomodacijskom načinu života koji je razrađen u društvenom sustavu Kine, u kojemu je obitelj bila središnja stanica, kako je to opisao J. L. Fung /2/, «od pet tradicionalnih društvenih odnosa koji 
čine odnos između vladara i podanika, oca i sina, starijeg i mlađeg brata, muža i žene, prijatelja i prijatelja, tri su porodični odnosi. Preostala dva, mada nisu porodični odnosi, mogu se izraziti terminima 'porodice'/3/». Da bi se osigurala harmonija između čovjeka i svijeta te čovjeka i drugog čovjeka, kako kaže Konfucije, potrebno je da se svatko drži unaprijed određene mjere. U području međuljudskih odnosa to su prava i dužnosti. Zato, «neka vladar bude vladar, ministar - ministar, otac - otac, a sin sin.»/4/. Mudrac je svaki čovjek koji zna tu mjeru i koji po njoj živi. «Opisan poetskim jezikom, to je čovjek koji se vozi na normalnostima svemira, jaši na preobražajima 6 elemenata i tako pravi izlete $\mathrm{u}$ beskonačno. On je zaista nezavisan čovjek te je njegova sreća apsolutna.»/5/. Ideal toga kineskog mudraca i uravnotežena čovjeka najbolje je opjevao Šao Jung u pjesmi «Sretno gnijezdo»:

Trideset godina živio je na obali rijeke Lo. Njegova čuvstva su čuvstva vatre i mjeseca; Njegov duh obitava na rijeci i jezeru.

Za njega nema razlika

Između niskog položaja i visokog čina, Između bogatstva i siromaštva.

Ne kreće se sa stvarima niti im prednjači. Ne zna za ograničenja i zabrane. Siromašan je ali ne tuguje, pije, ali nikad do pijanstva.

Ima mali ribnjak da tamo čita pjesme, ima prozorčić kroz koji gleda svijet; ima mala kola da razonođuje duh,

Ima veliko pero da njime uživa u svojoj volji ... Tako je 65 godina

Bio sretan čovjek. /6/

Ovaj životni ideal sažeo je F. L. Hauu u moralni kanon od 10 imperativa:

«Ne zaboravi na obiteljske dužnosti i harmoniju među braćom.

Ne krši zakone naroda i ne vrijeđaj vladara.

Ne zaboravi dostojanstvo učitelja i ne pokazuj znake nezahvalnosti.

Ne razbijaj odnose u obiteljskom klanu. Ne tuci se i ne uznemiruj selo i susjede.

Ne odbijaj pomoći onima kojima je pomoć potrebna.

Nemoj vrijeđati i ne zaboravi potrebu da uvećavaš duhovna dobra.

Ne koristi specijalne privilegije i nemoj drugima stvarati nezgode.
Ne odaji tajne drugih ljudi.

Nemoj kršiti nijedne zapovijedi.»/7/

Jednom riječju, sveopća ravnoteža se postiže tako da se nikada ne ide ispred, a pogotovo ne protiv prirode, jer ona najbolje rješava sve probleme; zato treba čekati i slijediti ritam prirode. To je istočnjačka adaptacija po maksimi Wu Wei (najjači si kad postupaš u skladu s prirodom). Za razliku od novovjekog zapadnjačkoga svjetonazora, ovaj je nazor, koji kaže da si najjači kada djeluješ kompatibilno s prirodnim tijekom, introvertan. Ekstrovertirani svjetonazor donio je čovječanstvu veliku moć, ali, što se danas dobro vidi, i velika iskušenja i stradanja. On nekritički izdiže čovjeka iznad prirode pa ga upravo zbog toga još više unesrećuje i poništava u svim njegovim stremljenjima jer ni uz svu tehniku kojom danas raspolaže, ne može pobijediti smrt, glad ni rat. Osjećajući da čovjek u ovoj karmi neće nikada pobijediti i osloboditi se sveopće tiranije, hinduski mislioci ne vjeruju u ekstrovertirani svjetonazor. Oni zato propovijedaju život kao napuštanje ove doline suza i dolazak u nirvanu gdje je smještena Leibnizova prestabilirana harmonija kao mjesto gdje se može živjeti u punoj slobodi, ljepoti i dobru.

Postizanje nirvane prvi je suvislo opisao Buda kao osmerokraki put:

1.Ispravno shvaćanje ili razumijevanje da je pobjeda želje i zavisti jedini put k sreći i da je osmerostruki put sredstvo do toga cilja.

2.Ispravan cilj ili težnja. Ne griješiti u osjetilnom preobilju. Raditi za sreću drugih.

3.Pravilan govor. Treba biti istinoljubiv i uvijek govoriti na takav način da se učvršćuje međusobno razumijevanje i prijateljstvo. Laži, klevetanje i psovanje mogu dovesti do svađa, pa čak i do nasilja, i tako poremetiti društvenu organizaciju i mir.

4.Pravilno djelovanje, što znači uzdržavanje od krađe, preljuba, ubijanja itd., a koje nalaže aktivnosti što vode dobrobiti drugih.

5.Pravilno ponašanje, što znači da nečiji način života ne smije štetiti drugima.

6.Pravilan napor, što uključuje mentalnu disciplinu radi uklanjanja zlih misli i razvijanja dobrih misli.

7.Pravilno mišljenje, što znači da treba biti jasno svjestan zala koja nastaju predavanje tjelesnim 
užicima, pa treba poduzeti korake da se oni uklone.

8.Pravilna meditacija, što uključuje mentalnu disciplinu i koncentraciju.»/8/

Budući da je nirvana transcendentna, sveopća se harmonija ne može postići ni na ovaj način pa bi se za uspješno stizanje u nirvanu trebalo što prije ubiti. Pomamni aktivizam i raspojasanost ekstrovertiranoga svjetonazora zapadne civilizacije također ne osigurava vječnu ravnotežu i sreću jer se u neurotičnom natjecanju s Bogom ne postiže željeni cilj, nego se u malim koracima ostvaruje samoubojstvo: opijanjem, drogiranjem i besmislenim aktivizmom. Religijske tehnologije za usrećivanje ljudi jačaju nadu u spas pomoću molitve i krjeposnoga življenja, ali ni to ne daje stvarne rezultate, nego samo manja ili veća psihička umirivanja. To krotko izdržavnje svih patnji najbolje je opisao poljski papa, Ivan Pavao II. u svojim poznatim diktama za sretniji i uravnoteženiji život u III. mileniju:

1.obrana svetosti ljudskoga života u svim prilikama

2.promicanje obitelji kao osnovne stanice društva

3.uklanjanje siromaštva promicanjem razvoja, smanjenjem dugova i otvorenošću međunarodnoga tržišta

4.poštivanje ljudskih prava u svim okolnostima, s osobitom pozornošću na najranjivije kategorije, djecu, žene i izbjeglice

5.razoružanje, smanjenje prodaje oružja siromašnim zemljama i učvršćivanje mira po završetku sukob

6.borba protiv velikih bolesti te pristup najsiromašnijih osnovnoj medicinskoj skrbi i lijekovim 7.očuvanje okružja i sprječavanje prirodnih katastrofa

8.stroga primjena međunarodnoga prava i konvencija./9/

Budući da nijedan od tri navedena modela sam po sebi ne može riješiti egzistencijalne probleme čovječanstva, u najnovije se vrijeme javlja humana ekologija kao najracionalnije i sintetsko rješavanje problema opće neuravnoteženosti. Ova humana ekologija počiva na epistemološ- koj sinergiji interdisciplinarnosti i svestranog analiziranja temeljnoga pojma stvarne, moguće i idealne ekološke uravnoteženosti.

3. Struktura i funkcija transcendencije, komunikacije, interakcije i entropije

Što je ekologija, kako danas shvaćati ekologiju i na koji način uspostavljati prstene u svim odnosima između čovjeka i svijeta - to su temeljna pitanja bez kojih se ne može prevladati današnji parcijalizam, pozitivizam i romantičarsko naklapanje o ekologiji. S obzirom da čovjek ne vlada apsolutnim spoznajama i da je smrtan, nije dovoljno izreći ni sintagmu «humana ekologija» jer ni ona ne može dosegnuti sferu apsoluta. Prema vodećim spoznajama što traju više od dva milenija, totalitet je strukturiran u tri temeljne sfere:

1. sfera transcendencije, 2. sfera povijesne interakcije i 3. sfera entropije.

\subsection{Sfera transcendencije}

P. T. de Chardin /10/ u svojim radovima je naglašavao da je prva sfera - noosfera, tj. da se ona sastoji od čiste energije ili promisli Boga i da tu više ne opstoje prostor i vrijeme, nego vlada opći zakon in minimis maxima (da su u najmanjem sadržane najviše tvorbe). To je Platonov topos noetos (svijet vječnih ideja iz kojih i po kojima sve nastaje putem tzv. polimerizacije kao sveopćeg procesa razgranavanja). Iz te sfere proizlaze i svi «vertikalni» zakoni koji nesmetano prolaze kroz ostale dvije sfere pojavnosti. Budući da je čovjek svojim osjetilnim sustavom ograničen u spoznaji njemu posve neshvatljivih entiteta, sfera transcendencije posve mu je zastrta. U ovoj izvorišnoj sferi čovjeku preostaje intuicija, vizija, molitva i Pascalova logic di core (logika srca). To znači da se ovoj omnipotentnoj sili treba stalno prilagođavati i tako hraniti nadu da će i čovjek nakon smrti dospjeti u tu sferu vječnoga mira, kako je govorio Kant.

Prevelika idolatrija i formalizacija vjere stalno je oscilirala između ikonodula i ikonoklasta, tj. onih koji Boga i Božju promisao antropomorfistički prikazuju i štuju te onih koji ruše perceptivne prikazbe. Ljudska spoznaja na sadašnjem je stupnju stohastička i ide po asimptotičkoj li- 
niji do točke omega. Kako smo mi danas znanstveno i tehnološki vrlo daleko od toga kraja, ekološka misao u ovoj sferi ostaje na nadanju. Što se tiče sfere zemaljske opstojnosti, tu vladaju stohastičke «horizontalne» zakonitosti po modelu: $a k o-$ onda $=u$ izvjesnom postotku. $U$ ovoj sferi uspostavlja se znanstvenim spoznajama i tehnološkim sustavima. Gnoseološki ova je sfera perceptivna i memorabilna pa se u njoj ljudi ponašaju po genomskom nasljeđu i kulturi vlastitoga razvoja s povijesnim ograničenjima.

\subsection{Povijesna komunikativna interakcija}

U ovoj se sferi, koju biologija naziva polimerizacijom, uniformni i dobro izbalansirani tipovi i vrste sve više disperziraju kao da im je cilj bijeg od svega što je opće i dobro. Zbog toga nastaju sukobi i ratovi u kojima jedni propadaju, a na njihovim razvalinama se izdižu drugi oblici pojavnosti. Zato je u ovoj sferi rat opći princip svega što jest i što nije. Ovaj proces detaljno opisuje opća i nacionalne povijesti. Pišu se povelje, sklapaju paktovi, ali je sve to uzaludno jer je u osnovi svega homofrausovska prijevara (prijevara čovjeka koji najprije vara druge, a potom i sam sebe obmanjuje). Stoga je danas cijeli svijet $\mathrm{u}$ interakcijama. Jedni čak propovijedaju da je kaos tih interakcija praishodište svega: $s$ jedne strane stvaranja kulture novih oblika, a s druge strane uništavanje postojećeg. U ovoj je sferi zato ekologija prosvjećivanja pokazala svu svoju nemoć jer se didaktičkim parolama kao što su: počisti svoj okoliš, više cvijeća - manje smeća, štedi energiju na svakom koraku, ne zagađuj vodu i zrak, ne sijeci šume - one su tvoja pluća itd. ne može se postići uravnoteženost. Naime, za svaku uspješnost potreban je susret i realni dogovor. Kako je neoliberalistička ekologija zasnovana na samovolji pojedinca (radi što god hoćeš, budi Bog, ti si glavni i sve je podređeno tebi i tvojoj sreći), ona se svodi samo na vapaj u dolini suza. S druge pak strane ova je ekologija opterećena i fantazmagoričnim idealizmom jer se više misli na pojedinačne želje, nego na načine i sredstva kako to ostvariti, a da to ne šteti i ne ograničava drugoga. U sferi kaosa zato vlada nesigurnost, nasilje, prijevare, narkomanija i sve vrste ovisnosti od anomalija su se pretvorile $u$ pravila ponašanja. Kaos se zato naziva «kontroliranim kaosom» iako kaos kontrolira, vodi i svakodnevno svojom entropijom uništava čovjeka.

\section{Sfera entropije}

Treća kozmička sfera je sfera entropije. Popularno rečeno to je područje «crnih rupa» gdje se skuplja sav otpad što nastaje u destrukciji oblika iz druge sfere. Što je entropija, znanosti još nije poznato. Treći Newtonov zakon pokušava govoriti o entropiji, ali čovjek još nema Arhimedovoga hvatišta pomoću kojega bi mogao jednom polugom dizati i razmještati kozmičke krhotine. Naravno, o entropiji je nužno razmišljati kako bi se shvatilo preobražaj svega što je mrtvo u ponovnu eksploziju (big bang) iz koje se rađa novi kozmos. Kako se entropija sve više ostvaruje zbog pada brzine, gubi se energija i čvrsti oblici. Mi još nismo dotle stigli, ali smo blizu. Naime, već naslućujemo da je entropija samo daljnji stupanj pada brzine kretanja. No, koji je daljnji pravac kozmičkih preobražaja, to je ljudima i njihovoj znanost zastrto.

\section{Suvremeni komunikativni problemi}

Što se može učiniti u sferi astrokozmičkih zbivanja? Razmišljanja su bila u okvirima mitskih projekcija i antropomorfizma. Nakon otkrića snažnih teleskopa i konstrukcije svemirskih letjelica naša su znanja prevladala antropomorfističku viziju svijeta. Fenomen globalnoga zatopljenja više se ne shvaća samo kao loše ljudsko djelovanje: zbog probijanja ozonskoga zaštitnog sloja u atmosferi ili zbog stalnoga zagrijavanja atmosfere zbog sve brojnijih industrijskih pogona, jer su se ekološke katastrofe i prije događale. Danas pouzdano znamo da je glavni uzročnik toplo-hladnih epoha mijenjanje nagiba Zemljine osi i njezine ekliptike, neovisno o ljudskom čimbeniku, četrdeset tisuća godina četiri puta su se izmijenile klimatske prilike. U pravilu su se svakih 10 tisuća godina smjenjivala doba arktičke hladnoće i tropske vreline. Kad je riječ o posljednjem ledenom dobu, samo na sjevernoj polutci ledom je bio okovan ne samo Arktik, nego i cijelo Baltičko more do PirinejskoAlpsko-Karpatskog planinskog koridora. Budući da se na tim prostorima više nije moglo živjeti, čovjek se pod utjecajem akomodacije seli na jug. I to je početak velike migracije stanovni- 
štva. Tek kad se Zemljina ekliptika počela kretati u suprotnom pravcu, ledeni pokrov Europe i sjeverne Azije počinje se topiti i smanjivati. Pojava pomicanja Zemljine osi djeluje i danas, što se može astrofizičkim tehnologijama i mjeriti. Međutim, ni danas se ne može ništa učiniti u sprječavanju tih oscilacija. U području narušenih odnosa između čovjeka i prirode čovjek je glavni čimbenik tih poremećaja. $\mathrm{U}$ zemljama u tranziciji, gdje stari odnosi još nisu odumrli, a novi nisu ojačali. Kako je to najbolje naglašavao E. Fromm, Ujedinjeni Narodi trebaju prihvatiti novi program normalnog, prirodnog i uravnoteženog razvoja pojedinca i zajednice. Industrija je gotovo prestala proizvoditi robu za podmirivanje normalnih ljudskih potreba, nego radi samo za izopačene potrebe bogataša, za glamuroznost, igru i svakojake razvratne i rekorderske borbe, prave ljudska riječi logos i promisao izgubile su svako ljudsko dostojanstvo. Merkantilistički izraz je relativizirao istinske vrijednosti, a samo sebe dekriminaliziralo toliko da nadvladavaju klevete i uvrede. Nakon što je Internet kao najmoćnije sredstvo za diseminaciju informacija danas elektroničku komunikaciju doveo do zagađivanja, pitanje osiguravanja i pružanja upravo validnih (zdravih) informacija postaje najvažniji problem suvremenoga čovječanstva. Po svome značenju to je pitanje jednako kao i fenomen izgradnje babilonske kule prije nekoliko tisućljeća. Kao što je onodobno taj veleprojekt propao zbog pomutnje brojnih jezika, tako i zbog današnje pomutnje u komunikaciji jezik često postaje sredstvo za zastiranje misli negoli sredstvo za njihovo rasvjetljavanje, objašnjavanje i stvaranje. Danas imamo najmoćnije medije za posredovanje i razmjenu informacija, a gotovo ni u čemu se ne razumijemo. Imamo i toliku količinu informacija da se «od stabala ne vidi šuma», i konačno, imamo vrlo malo operabilnih obavijesti kao naputaka za ispravno djelovanje, za ispravno življenje.

Austrijski psihijatar, Viktor Frankl, za taj sveopći anarhizam skovao termin «noogena neuroza», što znači neurozu zbog besmisla života. Nikada nismo imali više strojeva i drugih tehničkih pomagala, nikada nismo imali više znanstvenih spoznaja i nikada nismo imali više slobodnoga vremena, a nikada nije bilo više ratova, nasilja, kriminala, socijalne patologije (narkomanije, alkoholizma, pušenja, prostitucije i drugih opačina). U svim prijelaznim epohama ljudi u anarhičnim situacijama ne ponašaju se razumno, nego po svojim porivima. Ta je pojava posebno intenzivno vidljiva kad stara slika svijeta zamire, a nova se još nije afirmirala. Tada vlada korupcija, nasilje, prostitucija, narkomanija, bezvjerje itd. Bigbrotherovski homo fraus (obmanjivač i samoobmanjivač) i virtualni svijet elektroničkih medija idu još jedan korak dalje od tog besmisla, pa na TV ekranima prikazuju da je svijet virtualan i da je u njemu sve moguće (supermeni lete, automobili prometuju ne samo po zemlji, nego i u zraku i vodi, svijet dinosaura oživljuje i postaje uzorom bestijalnosti za današnjeg čovjeka). Suvremeni govornici i pisci natječu se u stvaranju bizarnosti kojom se hrani ovaj čovjek koji još kao vrsta nije umro, a novi se još nije stvorio. Da bi se oporavio od ove krize, svijet mora izraditi novu Povelju o ljudskim pravima jer je ova sadašnja već postala bespredmetna. Naime, ona bilježi oko 50 ljudskih prava, a da ni za jedno od njih ne jamči, niti navodi adresata koji bi ih trebao ostvarivati. Ona zato više nikomu nije potrebna pa je nužno što prije stvoriti novu Povelju ljudskih prava i dužnosti. Ovim naglašavanjem «i dužnosti» treći milenij bi mogao ostvariti dostojanstven život. Vodeći računa o funkcionalnoj povezanosti i reverzibilnosti ljudskih prava i njima pripadajućih obveza i dužnosti te o stupnju razvijenosti znanosti i tehnologije, predlaže se da se razumna i ostvariva ljudska prava svedu na skupine:

- pravo na zaštitu života, s dužnošću socijalnih službi, sudstva i policije da ga ostvaruje;

- pravo na rad i stvaralaštvo, s dužnošću države i pojedinca da ih ostvari;

- pravo na nacionalnu/ državnu pripadnost, s dužnošću adekvatnih institucija za ostvarivanje toga prava;

- pravo na slobodu vjeroispovijesti, s dužnošću države da ga štiti;

- pravo na privatno vlasništvo, s dužnošću sudova da ga štite;

- pravo na intimitet i osobnost, s dužnošću sudova, policije i novinara da ga štite.

Poljak Leszek Kolakowski /11/, u knjizi «Mini predavanja o maxi stvarima» (Mini wykłady o 
maxi sprawach») izradio je minucioznu fenomenologiju patologije suvremenoga života. Ova patologija ne ostaje samo na negativnostima, nego se predlažu i konkretna rješenja za uspostavu dobrobiti u društvu. Ova bi knjiga zato mogla biti valjana podloga za makro-političko i gospodarsko odlučivanje.

5. Gospodarski debalansi i uzročna poremećena komunikativna ravnoteža

Kad se prije dva desetljeća počelo pisati o globalizaciji kao o milenijskoj ravnoteži i ekološkoj regulaciji kao izlazu, nitko nije mogao ni slutiti da se mnogo toga od pomisli neće ostvariti.

U proslovu «milenijskog» dokumenta iz 1992. konstatirano je da su «Vlade Kanade, Sjedinjenih Država Amerike i Sjedinjenih Država Meksika odlučile da:

- ojačaju posebne veze prijateljstva i suradnje između svojih naroda

-doprinesu skladnom razvitku i širenju trgovine te osiguraju poticaj međunarodnoj suradnji

- stvore široko i sigurno tržište za robe i usluge proizvedene na njihovim područjima

- smanje izopačenosti u trgovini

-uspostave jasna i međusobno korisna pravila u trgovini

- osiguraju predvidljivi trgovinski okvir za poslovne planove i ulaganja

- unaprijede na temelji njihovih prava i obveza sukladno općim sporazumima o carinama i trgovini i na drugim multilateralnim i bilateralnim dokumentima o suradnji

- povećaju konkurentnost njihovih tvrtki na globalnim tržištima

- potiču stvaralaštvo i inovacije te unapređuju trgovinu robama i uslugama koje su predmetom prava o intelektualnom vlasništvu

- stvore nove mogućnosti za zapošljavanje i poboljšaju radne uvjete i životni standard na području njihovih zemalja

- poduzimaju sve gore utvrđeno na način koji je u skladu sa zaštitom i očuvanjem okoliša

• očuvaju svoju sposobnost za zaštitu javne dobrobiti

- unaprijede održivi razvitak

- ojačaju izradu i provođenje zakona i propisa o zaštiti i očuvanju okoliša te

-štite, unapređuju i provode temeljna prava radnika.»
Ovaj projekt u kojemu «nitko neće gubiti, a svi će dobivati», kako je povijest pokazala u sljedeća dva desetljeća, nije se pokazao ostvarljiv.

Kad je riječ o potpisivanju deklaracije iz Kyota za suzbijanje zatopljenja, i na tom se slučaju vidjelo da globalizacija preza ni profitom.

Kako je sve podložno povećavanju entropije (sve što je stvoreno ide po zakonima entropije od više energije prema nižoj). Druga etapa označava stabilizaciju zanosa i herojstva. Naime, oni se tada pretvaraju $u$ institucije koje neprestano gomilaju zakone, uredbe i poduredbe. Tada se u višim slojevima razvija dvostruka svijest, svijest koja u svojim izričajima i javnom komuniciranju postaje lakirovka koja prikriva nezasitne unutarnje porive koji su zapravo derivati jednog jedinog: biti prvi, biti Bog, a bez stvarnih snaga. Tada i zbog toga društvo se kao i danas neopozivo razdvaja u sloj siromašnih i sloj bogatih. Zbog oskudica u svemu što imaju bogati, siromašni se frustriraju, razvijaju mržnju i stvaraju borbene ideologije koje završavaju sukobima. Treća etapa je gubitak ravnoteže koja je bila postignuta te ulazak u anarhiju i ohlokraciju, nakon čega dotična etapa gubi svoj smisao i revolucionarnim se akcijama ponovno se pretvara u novu etapu. Mudrost kao sinteza zdravog razuma i uma s moralom i vjerom zato uvijek izbjegava krajnosti i ostvaruje maksimalno moguću povijesnu slobodu za svakoga, a ne samo za određenu elitu. Stara rimska maksima summa ius - summa iniuria (najbrojnije pravo je najveća nepravda) to stalno pokazuje jer kad se pravo putem brojnih zakona, uredaba i poduredaba tako usitni, pravnici u toj zbrci nalaze velik broj mogućnosti da se nevine osudi, a krivce oslobodi. U dekadentnim vremenima zbog toga se pod utjecajem neodgovorne slobode javlja potpuno pogrešno precjenjivanje tzv. ljudskih prava. To seže dotle da učenici danas štrajkaju jer se boje standardizirane državne mature. Oni zbog toga ne vole školu ni učenje, nego vole razvratni život u noćnim lokalima gdje ostaju do zore, a onda školu pretvaraju u spavaonicu.

6. Problemi u rješavanju ekološke, tehnološke i komunikativne ravnoteže

Kad se kaže «regulacija ili smrt», nije dovoljno to samo općenito tvrditi, nego je pritom još važnije na svakome mjestu činiti ono što pojedinac 
može. Poučna je $u$ tom smislu poznata parola «misli globalno, a radi lokalno». Kao što smo vidjeli iz prethodnih poglavlja, ekološka misao je uvijek u prvi plan stavljala sigurnost. To se vidi i iz samoga korijena grčke riječi oikos, što znači: dom, obitavalište, stanište, domaćinstvo. S razvojem znanosti i tehnologije ljudi su postali «gospodari» planeta Zemlje. Oni zato i sveopću ravnotežu tumače po svojoj mjeri, po mjeri čovjeka. Ekologija tada postaje jednosmjerna jer čovjek sve promatra sa stajališta svoje dobrobiti. Tijekom posljednjih pet stotina godina ona se razvija kao ljudska «svemoć». Pritom se, naravno, ne vidi da je i sam čovjek nemoćan u svojoj biti. Kako je čovjek postao glavnim destruktorom prirodne ravnoteže planeta Zemlje, V. Glavač navodi sedam skupina poremećaja prirodne ravnoteže i njezine spontane regulacije /12/:

1.Većina znanstvenika zastupa mišljenje da je čovjek pridonio globalnim klimatskim promjenama u 20. stoljeću

2.Između postupnog porasta stakleničkih plinova i postupnog porasta temperature u prizemnim dijelovima atmosfere u 20. stoljeću postoji korelacija koja je statistički dokazana sa 95 \% vjerojatnošću

3.Više klimatologa još uvijek zastupa mišljenje da je dosadašnje zatopljavanje još uvijek unutar prirodnih klimatskih oscilacija i da je takvih, relativno naglih, promjena već bilo u povijesti Zemlje. Oni sumnjaju i u ispravnost prognoza današnjih računalnih modela. Međutim i oni nisu sigurni jesu li njihove ocjene ispravne i oprezni su u svojoj kritici. $S$ druge strane nije isključeno da staklenički plinovi prouzrokuju nagle klimatske promjene i u tijeku jednog desetljeća. Nadalje, kako je već naglašeno, nije još razjašnjena uloga aerosola u procesu globalnoga zatopljavanja. Oni doduše ublažuju proces zatopljavanja, ali ne mijenjaju osnovni trend

4.Po vrlo opreznim računalnim prognozama povisit će se prosječna globalna temperatura do godine 2100. za 2 stupnja C, što bi bio najviši porast temperature $\mathrm{u}$ posljednjih 10000 godina. No sve se više računa i s povišenjem prosječne globalne temperature za punih 5,8 stupnjeva C. 5.Više temperature uvjetuju jače isparavanje vodenih površina, što znači ukupni porast godišnjih količina padalina. U nekim će klimatskim područjima opskrba vodom biti veća, u drugima manja, što znači da će pri novoj oborinskoj preraspodjeli biti regionalnih dobitnika i gubitnika.

6.Po isto tako opreznim kompjutorskim modelima razina mora i oceana narast će do godine 2100. za oko $35 \mathrm{~cm}$.

7.Promjena klime i razine mora prouzročit će do kraja 21. stoljeća, ako se ne poduzmu radikalne mjere za zaštitu okoliša, ogromne promjene u biosferi i snažno će utjecati na dalji razvoj političkih, gospodarskih i društvenih prilika. Predviđa se premještanje dosadašnjih klimazona od juga na sjever koje ekosustavi neće moći tako brzo slijediti, zaslanjivanje tala u nizinskim priobalnim područjima i ušćima rijeka, nedostatak pitke vode, nedostatak hrane, rasprostranjenja zaraznih bolesti, migracije stanovništva, neizdržive vrućine u gradovima. Zatopljavanje atmosfere od posljednjega ledenog doba do danas od 4 do 5 stupnjeva $C$, koje je trajalo 5000 godina, zbiva se danas, samo u razdoblju od stotinjak godina.»/13/.

Doda li se ovim konstatacijama stalno povećavanje sumpora $\mathrm{u}$ atmosferi, što izravno uzrokuje propadanje šuma (od tzv. kiselih kiša), količina kisika će se smanjivati, a količina ugljičnog dioksida će se stalno povećavati. Budući da totalna devastacija biljaka već danas uzrokuje pojačano smanjivanje kisika, neposredna $\mathrm{u}-$ grozba ljudi i životinja postaje alarmantna. Ozbiljne studije ukazuju i na još jednu, možda i najopasniju, poremetnju o kojoj se još uvijek javno ne govori. Ubrajajući u to i uvećavanje otpadaka i smeća što ga čovjek proizvodi, u ovom će se stoljeću formirati labilni sloj na Zemljinoj kori koji će se zbog sadašnjeg stanja gravitacije vrlo lako odcijepiti od Zemlje te time uzrokovati njezino umiranje i transformaciju u status bijeloga patuljka koji glavinja svemirom. Sve ovo urgentno traži da se problemu rješavanja ekološke ravnoteže dade prioritetno značenje, a ne da ostanemo na kozmetizaciji (poput onih plitkih ideologema «više cvijeća - manje smeća» ili svođenja na minornu kozmetizaciju tla).

Kako navodi V. Glavač, neke se akcije i rezolucije u tom smislu pokreću, kao npr.:

- «utvrđivanje planetarne osnove dugoročne politike zaštite; 
-izrada odgovarajućih znanstvenih i stručnih studija i elaborata;

- utvrđivanje izvora financiranja;

- aktualiziranje i usklađivanje svih propisa koji se odnose na to područje;

- osnivanje odgovarajućih organizacija;

- objedinjavanje akcija svih službi i institucija koje djeluju na području uređenja i zaštite čovjekove sredine;

- provođenje djelotvorne kontrole;

- informiranje javnosti i uključivanje svih društvenih struktura u ovu akciju;

-veće korištenje obrazovnih institucija i sredstava javnoga informiranja za upoznavanje mladeži i građana s ambijentalnim i drugim vrijednostima okoline i važnosti zaštite i unapređenja čovjekove sredine.» /14/

Remećenje prirodne ekološke ravnoteže ne samo da kuca na vrata svih ljudi, nego ono i izravno prijeti uništenjem planeta Zemlje i njegovih stanovnika.

7. Znanstveni doprinosi transcendntne komunikacije $\mathrm{u}$ tehnološkom razvoju humane ekologije

Knjiga poljskog filozofa Leszeka Kolakowskog pod naslovom: Mini predavanja o maksi problemima. U svojim diktama predstavlja popularnu enciklopediju o tome što i kako djelovati u svakodnevnom životu. Ona nas osvješćava. Poljski autori Tadeusz Kotarbiński čije je djelo «Traktat o dobrom djelovanju» (objavljen u nas) i Bogdan Suchodolsk dojmljivo pišu o zagađivanju čovjeka, društva i Zemlje u cjelini. Filozof L. Kolakowski svojim je diktama povezao i prokomentirao bit ekološkoga debalansa te je konkretizirao nastojanja poboljšavanja po maksimi in minimis - maxima. Najmanje a ujedno najviše što svatko od nas može u tom smislu učiniti jest mudro ponašanje (kao sinteza srca, uma i djela). Tu sinergijsku mudrost Kotarbiński je nazvao prakseologijom kao oznanstvenjeno djelovanje. On je i tvorac modernog pojma invigilacije. To je bdijenje i nadziranje svakog procesa. Sva ta dostignuća Kolakowski sintetizira i svodi pod antičku mudrost Aristotela Panta metron estin. Ta maksima živi više od dva tisućljeća, a kad je riječ o mudrosti i ekološkom uravnotežavanju, mjera je ona idealna točka koja i danas (danas još i više nego u doba Aristotela) vrijedi kao i kod «starih Kineza». Ekološki se ne može postići ravnoteža nijednog sustava bez sile. Ona je zapravo gravitacijska moć održavanja identiteta. No kad je sila slijepa, ona je strašna destruktivna moć. Sila je, dakle, poželjna i opravdana samo kad je dinamogeni faktor dobra, tj. «kad je usmjerena protiv ropstva, zločina, agresije i tiranije.». /15/ Budući da je priroda inkarnacija božanstvene sile, ona je vidljiva i dostupna čovjeku pa ju čovjek mora poštivati kao prisutnu neprisutnost savršenstva transcendencije. Priroda je dostupna našim osjetilima. Danas je poznato postojanje patogenih oblika prirode kao što su bakterije i virusi, ali se još ne zna njihova svrha, uloga u živome svijetu, pa je stalnim produbljivanjem ekološke regulacije potrebno i to dokučiti. /16/

\section{Zaključno razmatranje}

Kao što se iz svega vidi, multifaktorskom analizom pokušaj je ukazati na probleme i dileme $s$ kojima se susreće ekološka misao. Naime, genetskom metodom se pratio razvoj ekološke misli od neosviještenoga spontaniteta do današnjeg funkcionalnog partikularizma koji je pokazao da je samo svemoćna nemoć.

Prva upozorenja bila su da izlaz treba tražiti holističkom metodologijom jer jednostrana metodologija ne vodi $\mathrm{k}$ uspjehu. Ta su upozorenja dovela ekologiju do prekretnice: ili i dalje jalovo ići pars pro toto, ili tražiti svestranu analizu na temelju komparacije i stalnog provjeravanja sinergijskoga modela u ekologiji. Suvremena kriza ponukala nas je da interdisciplinarnim putem prikupljamo, kategoriziramo i generaliziramo povijesno respektabilna ekološka iskustva. Broj 3 još uvijek dominantan za makroklasifikaciju (vjerski trinitet: Otac, Sin i Duh sveti, Hegelova formula: teza - antiteza = sinteza, formula stohastičke epistemologije: ako onda $=\mathrm{u}$ izvjesnom postotku), prihvatila ga je $\mathrm{i}$ najnovija ekološka znanost koja kozmički totalitet dijeli na tri makro- sfere: sfera transcendencije (koja se različito naziva: Bog, providnost, promisao, apsolutna energija, duh, prestabilirana harmonija itd.), sfera čovjekovoga oikosa kao dinamičnog trodimenzionalnog prostora (gdje vlada srednji stupanj sinergijskih tvorbi) i sfera entropije (gdje se energija pretvara u materiju i čeka novi big bang kao eksploziju u kojoj 
započinje novi ciklus). U sferi transcendencije čovjekova participacija je akomodacija, odnosno vjera i molitva $\mathrm{s}$ vječnom nadom $\mathrm{u}$ dobar konačni ishod. Vjera optimistički gleda na ekološki spas. U sferi zemaljskoga oikosa mogućnosti čovjeka mnogo su više prisutne jer ljudi s današnjom tehnologijom i znanošću mogu svojim aktivnostima uravnotežavati mnoge procese kao što su: održavanje čistoće okoliša (zdrave vode, zraka i tla), uređivanje međuljudskih odnosa, reguliranje industrijske proizvodnje za podmirivanje normalnih ljudskih potreba, optimalizacija rekreacije u slobodnom vremenu. Humana ekologija iznad svega naglašava ulogu čovjeka u svemu tome, a napose u razvijanju samoregulacije koja osigurava kvalitetniji život. U sferi entropije kao odlagališta iskorištene energije mnogo biva nejasnog. Ako se nastoji proniknuti u smisao opstojnosti entropije uopće, tada nam se nude dva glavna rješenja. Po jednima entropijom sve završava, to je rasap, popularno rečeno - odlagalište kozmičkog smeća - jedno veliko ništavilo. Druga je teorija cikličkog razvoja, čiji je prvi autor Heraklit, koja tvrdi da se sve ponavlja, od vode, preko zraka do vatre te od vatre njezinim hlađenjem ponovno preko zraka do vode. Unutar ove teorije sve se opisuje spiralnim kretanjem. Ova teorija je prihvatljivija za ostvarivanje progresa. Zato joj mnogi futurolozi daju prednost. Budući da su zatopljenja atmosfere, dizanja morske površine zbog otapanja ledenjaka na Arktiku i Antarktiku, zatim pojave bolesti, ratova i drugih anomalija u ljudskom rodu postale masovne pojave te se zbog svega toga danas nalazimo zaista na prekretnici, stara parcijalistička ekologija mora pronalaziti sve više i više stupnjeve reguliranog ustrojstva na globalnom i lokalnom planu djelovanja. Nestabilnost ljudskoga makro- i mikro-sklopa s tim u svezi uzela je toliko maha da prijeti rasapu i na području zdravlja za big brotherizmom, exploziv emisijama, horrorshowovima pa zbog povećavanja svakojakih ovisnosti prijeti teškim mentalnim poremećajima. Radi svega toga tvrdi se da je došlo vrijeme odumiranja neuronskog, prirodnog čovjeka koji se sve više pretvara u kiborga i robota. Optimistički raspoloženi futurolozi razvijaju sekulariziranu koncepciju raja koja polaže sve nade $\mathrm{u}$ komercijalizaciju interplanetarnih letova, ne bi li se našlo za čovječanstvo novo stanište na drugim planetima. Uza sve teškoće i neostvarivosti mi smo optimisti jer nas je povijest uvjerila da pri svakom tisućljeću, započinje novi ciklus i u društvu. Kako je dobro pisao i hrvatski književnik Miroslav Krleža, «Nigdar ni tak bilo da ni nekak bilo, pak ni vezda ne bu da nam nekak ne bu.» /17/

Bilješke

/1/ Piaget, Jean (1971.): Mudrost i zablude filozofije, Nolit, Beograd

/2/ Fung, J.L. (1972): Historija kineske filozofije, Nolit, Beograd

/3/Fung, J.L: Historija kineske filozofije, Nolit, Beograd, 1972., str 143.

/4/Ibidem, str. 145.

/5/Ibidem, str.145.

/6/lbidem, str. 146.

/7/ Ibidem, str. 147.

/8/ Ibidem, str. 82

/9/ Ivan Pavao II: Osam papinih sugestija, Glas koncila, 3. str.4, Zagreb, 20.1.2002.

/10/ Chardin, de P.T.:Budućnost čovjeka, Crkva u svijetu, Split, 1970.

/11/ Kolakowski, L.: Mini Wyklady o maxi sprawach, Wydawnictwo Znak, Kraków, 2003.

/12/ Glavač, Vjekoslav (2001): Uvod u globalnu ekologiju, Hrvatska sveučilišna naklada, Zagreb

/13/ Ibidem

/14/Ibidem, str.176.

/15/Ibidem, str. 73-79

/16/Ibidem, str.122-127

/17/ Krleža, M: Balade Petrice Kerempuha, Zagreb, 1970.

Literatura

1. Filipović, Vladimir (ur.)(1984): Filozofijski rječnik, Matica hrvatska, Zagreb

2. Ivan Pavao II. (2002): Osam Papinih sugestija, Glas Koncila br. 3., 20. siječnja 2002, str. 4., Zagreb

3. Perkins, John (2008): Prikriveni ekonomski ubojica, Edicije Božičević, Zagreb

4. Plenković, J. (2002): Humana ekologija, Sveučilište u Rijeci, Rijeka

5. Plenković, J. (2004.): Ekologia humanistyczna wobec globalizacji, Uniwersytetu Rzeszowskiego, Rzeszów

6. Plenković, Juraj; Plenković, Mario; Radoš, Goran (2008):Ecology and technology // Technika-Informatyka Edukacja / Furmanek, Waldemar (ur.).Rzeszow : University of Rzeszow, Str. 231-241 
7. Plenković, J. i Plenković M. (1998.): Društvo, znanost i tehnologija, Sveučilište u Rijeci, Rijeka

8. Plenković, J., Persi T., Kostić Bobanović M.(2000.): Giving Profile to the Economy of Gorski Kotar, Universita degli studi di Perugia, Perugia

9. Plenković, Mario; Hadžić, Slobodan; Plenković, Juraj ( 2008): Istota czasu wolnego // Wartosci w pedagogice / Waldemar Furmanek (ur.).Rzeszow : Zaklad Dydaktyki i Techniki i Informatyki Uniwersytetu Rzeszowskiego, Str. 58-70.

10. Plenković, Mario; Hadžić, Slobodan; Plenković, Juraj (2008):Society, science and technology // Technika-Informatyka Edukacja / Furmanek,
Waldemar (ur.).Rzeszow : University of Rzeszow, Str. 29-37.

11. Plenković, Mario; Tomažič, Tina; Plenković, Juraj (2008):A fundamental dependance the roles of profit and success in mass media industries // Wypalnie zawodowe pracownikow sluzb spolecznych / Teresa Zbyrad (ur.).

Stalowa Wola : Katolicki Uniwersytet Lubelski Jana Pawla II w Lublinie, Str. 573-578.

12. Suchodolski, Bogdan (1974.): Suvremeni problemi filozofije odgoja, Pedagogija br. 4, Beograd

\title{
HUMAN ECOLOGY AND TECHNOLOGY OF TRANSCENDENT COMMUNICATION
}

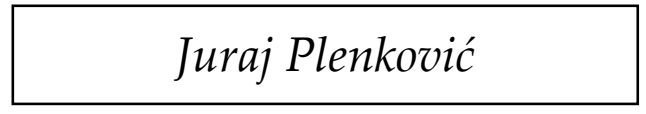

University of Rijeka, Rijeka, Hrvatska

\begin{abstract}
In this paper author is giving diachrony and sinchrony analysis of historical and technological possibilities of ecology and transcendent communication. He is using multilateral methodolodgy of accomplishments of contemporary ecological and communication transcendent thought. It is a general thesis that the world today is in a global crisis and ecology and technology in a new human challenge which is becoming dominant mark of human thinking, behaviour and acting in contemporary communicational and technical world. Modern life is setting human ecology in the first plan. Author is empasising in his paper that ecology and technology shouldn't be left on their own, but all technologies must be used in human communicational manner with the goal of reaching maximal technological terms of communicational sorroundings, space, culture, tradition and educative skills of all citizens.
\end{abstract}

Key words

ecology, communication, humanity

First published in Informatologia, Vol. 41 No.4, 2008. 